\title{
ASOSIASI FAKTOR PEMELIHARAAN DAN STATUS INFEKSI NEWCASTLE DISEASE (ND) PADA PETERNAKAN AYAM BURAS DI KECAMATAN TELUK AMBON
}

\author{
Astri D. Tagueha* \\ Jurusan Peternakan, Fakultas Pertanian, Universitas Pattimura \\ Jl. Ir.M. Putuhena, Kampus Poka, Ambon 97233 \\ *Email : acitunpatti@gmail.com
}

\begin{abstract}
ABSTRAK
Penelitian ini bertujuan untuk mengetahui status infeksi Newcastle Disease (ND) pada ayam buras di tingkat peternakan tradisional, mengidentifikasi faktor pemeliharaan yang berpengaruh, serta mengetahui hubungan antara kedua peubah tersebut. Sebanyak 21 peternakan dipilih secara purposive sampling dari tiga desa yaitu Hunuth, Rumah Tiga, dan Hative Besar. Titer positif ND dinyatakan jika uji Hemaglutinasi Inhibisi (HI) bernilai $\geq 2^{4}$. Analisis data menggunakan statistik deskriptif dan risk relative (RR) untuk menjelaskan asosiasi variabel dengan titer positif. Hasil penelitian menunjukkan dari 93 sampel darah ayam yang diuji HA HI, terdapat 51,61\% yang memunculkan titer antibodi. Pada tingkat peternakan, diketahui 66,67\% peternakan berstatus positif terinfeksi ND dengan rincian Hunuth 19,05\%, Rumah Tiga 19,05\%, dan Hative Besar 28,57\%. Faktor-faktor yang memiliki asosiasi positif dengan status infeksi di tingkat peternakan adalah : penggunaan kandang $(1,88)$, perlakuan kotoran $(1,46)$, sumber air $(1,33)$, perlakuan ayam sakit $(1,64)$, perlakuan ayam baru $(1,54)$, perlakuan ayam mati $(1,64)$, dan penggunaan pagar $(1,5)$.
\end{abstract}

Kata kunci: Faktor pemeliharaan, status infeksi, Newcastle disease (ND), peternakan tradisonal, ayam buras

\section{ASSOCIATION OF MAINTENANCE FACTOR AND INFECTION STATUS OF NEWCASTLE DISEASE (ND) ON NATIVE CHICKEN FARM IN TELUK AMBON SUB-DISTRICT}

\begin{abstract}
The objectives of this study were to determine the status of Newcastle Disease (ND) infection in native chicken at traditional farms, identifying risk factors, and knowing the association between these two. A total of 21 farms were purposively selected from three villages namely Hunuth, Rumah Tiga, and Hative Besar. Positive titre of ND was indicated if Hemaglutination Inhibition (HI) test is $\geq 24$. The data were analyzed using descriptive statistics and risk ratio (RR) to describe association between variable and positive titre. The results showed from 93 chickens' blood sample there were $51,61 \%$ have ND antibodies. At the farm level, $66.67 \%$ of farms are positively infected , i.e : Hunuth 19.05\%, Rumah Tiga19.05\%, and Hative Besar 28.57\%. Factors that are positively associated with infection status at farm level are respectively :cage usage (1.88), manure treatment (1.46), water source (1.33), treatment of sick chicken (1.64), treatment of new chicken (1.54), treatment of dead chicken (1.64), and fence usage (1.5).
\end{abstract}

Key word: Maintenance factors, infection status, Newcastle disease (ND), traditional farming, native chicken

\section{PENDAHULUAN}

Newcastle disease (ND) atau tetelo merupakan penyakit viral yang berdampak ekonomis bagi peternak karena tingginya angka mortalitas, penurunan produksi telur dan daya tetas telur secara signifikan, serta menghambat pertumbuhan (Tabbu, 2000 ; Santhia, 2003). Penyakit ini mewabah pada musim pancaroba atau pergantian musim, dari musim kemarau ke musim penghujan atau sebaliknya. Kejadian juga meningkat pada saat cuaca terlalu panas dimana ayam mengalami stres berat, kondisi daya tahan tubuh ayam menurun, dan kekebalan yang juga ikut menurun (Wibowo \& Amanu, 2010). Virus ND yang berasal dari famili paramyxoviridae ini menyerang semua jenis unggas, baik unggas liar maupun domestikasi. Inhalasi merupakan jalur penularan utama. Virus dilepaskan dalam jumlah besar oleh hospes terinfeksi melalui ekskreta dan mengontaminasi udara, pakan, air minum, serta peralatan kandang (Alexander, 2001 ; Soeharsono, 2005 ; CFSPH, 2008). 
Spesies ayam buras yang dipelihara secara ekstensif menjadi sasaran utama penyebaran virus ND. Rajab \& Papilaya (2012), menduga virus ini turut bertanggung jawab terhadap $70 \%$ angka kematian ayam buras di Kota Ambon setiap tahunnya. Anggapan bahwa ayam buras memiliki daya tahan tubuh lebih baik telah menyebabkan mayoritas pemilik peternakan, terutama yang berskala rumah tangga, mengabaikan aspek manajemen kesehatan, misalnya cara pembersihan kandang dan peralatan secara benar atau pentingnya vaksinasi. Menurut Soeharsono (2005), keberhasilan pengendalian ND di Indonesia bergantung pada program vaksinasi mengingat banyak faktor resiko yang turut berkontribusi.

Penyebaran penyakit ND sangat cepat terjadi melalui kontak langsung dengan ayam sakit, kotoran, ransum, air minum, kandang, tempat ransum atau minum, peralatan lainnya yang tercemar oleh kuman penyakit, melalui pengunjung, serangga, burung liar, dan udara. Bahkan penyebaran melalui udara dapat mencapai radius $5 \mathrm{~km}$ (Syukron et al., 2013).

Pemeliharaan ayam buras secara komersil umumnya dijumpai pada peternak di Kecamatan Teluk Ambon. Data resmi menunjukkan adanya fluktuasi populasi, dimana pada tahun 2016 hanya 1.433 ekor atau turun drastis 92,08\% dari tahun 2012 (BPS, 2017). Diduga infeksi berulang dari ND yang dilaporkan peternak setiap tahun menjadi salah satu penyebab. Dugaan ini perlu divalidasi dengan mengetahui tingkat insidensi pada jangka waktu tertentu.

Faktor pemeliharaan seperti keberadaan kandang, frekuensi membersihkan kandang dan peralatan, cara menangani kotoran, perlakuan terhadap ayam sakit dan keberadaan pohon besar di sekitar kandang dikategorikan sebagai faktor-faktor predisposisi yang secara tidak langsung menentukan penyebaran ND baik di dalam satu lokasi peternakan maupun antar peternakan lainnya (Pertulla, 2009 ; Prasetyo, 2012 ; Nugraha, 2015). Program pengendalian terpadu harus dimulai dengan mengetahui status infeksi ND pada tingkat peternakan. Hal ini penting untuk memetakan laju penyebaran penyakit di lapangan sekaligus mengidentifikasi berbagai faktor resiko. Penelitian ini bertujuan untuk mengetahui status infeksi ND pada ayam buras di tingkat peternakan tradisional, mengidentifikasi faktor pemeliharaan yang berpengaruh, serta mengetahui hubungan antara keduanya.

\section{BAHAN DAN METODE}

Penelitian ini terlaksana pada bulan April sampai Mei 2017. Pengambilan data berupa sampel darah ayam dan wawancara dengan responden dilakukan pada tiga (3) desa yang dipilih secara purposive sampling, yaitu Desa Hunuth, Rumah Tiga, dan Hative Besar. Pemilihan lokasi tersebut juga mempertimbangkan kondisi geografis dan topografi wilayah berkenaan dengan penyebaran ND, yaitu wilayah pegunungan ke dataran rendah. Wawancara berhasil dilakukan terhadap 21 pemilik peternakan ayam buras. Jumlah sampel darah yang digunakan ditentukan dengan rumus deteksi penyakit (Martin et al., 1987) yaitu :

$$
\mathrm{n}=\left[1-(1-\mathrm{a})^{1 / \mathrm{D}}\right][\mathrm{N}-(\mathrm{D}-1) / 2
$$

Keterangan :

$\mathrm{n}=$ jumlah sampel

$\mathrm{a}=$ error

$\mathrm{D}=$ jumlah ternak sakit

$\mathrm{N}=$ populasi

Dengan tingkat konfidensi 99\%, asumsi prevalensi penyakit ND di Kecamatan Teluk Ambon sebesar 5\%, dan populasi ayam sebanyak 1.433 ekormaka diperoleh jumlah minimal sampel darah harus dikoleksi dari 86 ekor ayam buras dimana setiap peternakan diambil 4 ekor ayam.Jumlah sampel yang berhasil diambil berasal dari 93 ekor.

Peralatan yang dibutuhkan yaitu syringe disposable ukuran $3 \mathrm{cc}$, coolbox, tupperware, pipet pasteur, eppendorf, tusuk gigi, kapas, alkohol 70\%, centrifuge, tabung reaksi ukuran $10 \mathrm{ml}$, beaker gelas ukuran $600 \mathrm{ml}$, tabung ukur $10 \mathrm{ml}$, rak, mikroplate $\mathrm{v}$, stopwatch, mikropipet, dan ventip. Sedangkan bahan yang digunakan meliputi larutan alsever's, larutan PBS ( $\mathrm{pH} 7,2)$, alkohol 70\%, dan antigen ND produksi PUSVETMA.

Pemeriksaan titer menggunakan metode Hemaglutinasi dan Hemaglutinasi Inhhibisi (HA-HI). Titer positif ND dinyatakan jika uji Hemaglutinasi Inhibisi (HI) bernilai $\geq 2^{4}$ (OIE, 2009). Penentuan status infeksi peternakan dilakukan jika $75 \%$ sampel yang mewakilinya memiliki titer ND positif.

Pengujian HA HI mengacu pada standarOffice International Epizootic(OIE) yang secara sistematis dapat diringkas berikut ini : (1) pembuatan sel darah merah (sdm) ayam 1\%, (2) pembuatan suspensi sel darah merah (SDM) ayam 10\%, (3) penyiapan suspensi SDM 1\%, dan (4) uji HA-HI.

Prosedur uji Haemaglutination (HA) mengikuti langkah-langkah sebagai berikut : (1) Siapkan mikroplate dasar V ; (2) Masukan 0,025 ml larutan PBS ke dalam semua sumuran dengan menggunakan mikropipet tunggal ; (3) Tambahkan 0,025 ml Antigen (Ag) ke dalam sumuran 1 ; (4) Homogenkan AntigenPBS pada sumuran 1 , kemudian pindahkan $0,025 \mathrm{ml}$ ke dalam sumuran 2 dan seterusnya sampai sumuran 11 (pengenceran seri). Buang 0,025 ml campuran AgPBS dari sumuran 11 ; (5) Sumuran 12 digunakan untuk kontrol SDM ; (6) Tambahkan 0,025 ml larutan SDM $1 \%$ ke dalam semua sumuran ; (7) Goyangkan mikroplate membentuk angka delapan ; (8) Diamkan pada suhu ruang selama 30-60 menit ; (9) Hasil positif berupa haemaglutinasi seperti pasir tersebar ; dan (10) Setelah didapatkan hasil HAU maka hasil tersebut digunakan untuk pengujian lanjut HI.

Prosedur uji Haemaglutination Inhibition (HI) meliputi tahapan berikut ini : (1) Siapkan mikroplate 
dasar V ; (2) Masukkan 0,025 larutan PBS ke dalam semua sumuran dengan menggunakan mikropipet tunggal ; (3) Masukkan 0,025 ml serum ke dalam sumuran 1 ; (4) Homogenkan serum-PBS dengan menggunakan mikropipet tunggal, kemudian pindahkan $0,025 \mathrm{ml}$ ke dalam sumuran 2 dan seterusnya sampai sumuran 11 (pengenceran berseri). Buang 0,025 $\mathrm{ml}$ sampuran antigen-PBS dari sumuran 11 ; (5) Sumuran 12 digunakan untuk kontrol SDM ; (6) Tambahkan 0,025 $\mathrm{ml}$ antigen 32 HAU ke dalam semua sumuran kecuali sumuran 12 ; (7) Goyangkan mikroplate membentuk angka delapan ; (8) Diamkan pada suhu ruang selama 30 menit ; (9) Tambahkan $0,025 \mathrm{ml}$ larutan SDM 1\% ke dalam semua sumuran ; (10) Goyangkan mikroplate membentuk angka delapan ; (11) Diamkan pada suhu kamar selama 30 menit ; dan (12) Hasil positif berupa haemaglutinasi sel darah merah. Jika mikroplate dibalik maka akan terlihat seperti leleran air mata, sama seperti kontrol SDM.

Analisis data dilakukan secara deskriptif. Asosiasi antara titer antibodi dan faktor-faktor yang berhubungan (penggunaan kandang, frekuensi membersihkan kandang, frekuensi membersihkan tempat pakan dan minum, perlakuan kotoran, sumber air minum, perlakuan ayam sakit, perlakuan ayam baru, perlakuan ayam mati, kontak dengan burung liar, penggunaan pagar kandang, dan keberadaan pohon) akan dianalisis dengan Risk Relative atau RR (Martin et al., 1987) dengan rumus pada tabel kontingensi $2 \mathrm{x}$ 2, adalah :

$$
R R=\frac{(D+/ F+)}{(D+/ F-)}=\frac{a /(a+b)}{c /(c+d)}
$$

Keterangan :

a : ayam dengan titer $\geq 2^{4}$ dan terpapar faktor

b : ayam dengan titer $<2^{4}$ dan terpapar faktor

c : ayam dengan titer $\geq 2^{4}$ dan tidak terpapar faktor

d : ayam dengan titer $<2^{4}$ dan tidak terpapar faktor

Jika nilai $\mathrm{RR}<1$ menandakan rendahnya pengaruh faktor resiko, $R R=1$ tidak ada pengaruh, dan RR > 1 pengaruh kuat antara faktor resiko dan penyakit.

Tabel 1. Hasil Pemeriksaan Titer Antibodi ND Pada Ayam Buras di Kecamatan Teluk Ambon

\begin{tabular}{lcccc}
\hline \multirow{2}{*}{ Desa } & \multirow{2}{*}{ Jumlah Sampel (ekor) } & \multicolumn{2}{c}{ Titer antibodi ND } & \multirow{2}{*}{ Total (\%) } \\
\cline { 3 - 4 } & & Ada $(\%)$ & Tidak ada (\%) & \\
\hline Hunuth & 39 & 16,13 & 25,81 & 41,94 \\
Rumah Tiga & 30 & 9,68 & 22,58 & 32,26 \\
Hative Besar & 24 & 25,80 & 0,0 & 25,80 \\
\hline Total & 93 & 51,61 & 48,39 & 100 \\
\hline
\end{tabular}

Tabel 2. Status Infeksi ND Di Tingkat Peternakan Ayam Buras di Kecamatan Teluk Ambon

\begin{tabular}{lcccc}
\hline \multirow{2}{*}{ Desa } & Jumlah Sampel & \multicolumn{2}{c}{ Status infeksi ND } & \multirow{2}{*}{ Total (\%) } \\
\cline { 3 - 4 } & Peternakan & Positif $(\%)$ & Negatif (\%) & \\
\hline Hunuth & 5 & 19,05 & 4,76 & 23,81 \\
Rumah Tiga & 8 & 19,05 & 19,05 & 38,10 \\
Hative Besar & 8 & 28,57 & 9,52 & 38,09 \\
\hline Total & 21 & 66,67 & 33,33 & 100 \\
\hline
\end{tabular}

HASIL DAN PEMBAHASAN

\section{Status Infeksi ND Pada Tingkat Peternakan Ayam Buras}

Hasil penelitian (Tabel 1) memperlihatkan terdapat 50,5\% dari 93 sampel darah memiliki titer antibodi terhadap ND. Temuan ini menandakan seperdua dari populasi ayam buras di Kecamatan Teluk Ambon pada saat penelitian sedang atau sudah terpapar virus.

Pada tingkat peternakan diketahui sebanyak $66,67 \%$ positif terinfeksi ND (Tabel 2). Artinya, pada saat penelitian dilakukan $19,05 \%$ peternakan buras di
Hunuh dan Rumah Tiga serta 28,57\% peternakan di Hative Besar sementara atau telah terpapar virus ND. Variasi keterpaparan pada tingkat peternakan dipengaruhi oleh beberapa kondisi seperti kesehatan ayam, jumlah virus yang menginfeksi, dan perbedaan waktu infeksi (Purnamawati \& Sudarnika, 2008 ; Bernadeta et al., 2015).

Semua peternakan yang didatangi tidak pernah menerapkan vaksinasi sehingga titer yang terdeteksi dianggap sedang terinfeksi virus ND. Lebih lanjut, pada saat pengambilan sampel teramati ayam buras dengan gejala klinis mirip ND seperti lesu, tidak mampu berdiri, serta feses cair dan berwarna putih 
kehijauan yang ditemukan pada beberapa lokasi peternakan.

Penentuan positif terinfeksi didasarkan pada aturan OIE yaitu jika titer antibodinya pada uji $\mathrm{HI} \geq 4$ $\log 2$ (OIE, 2009). Titer antibodi yang ditemukan berkisar dari $1 \log 2$ hingga $10 \log 2\left(2^{1}\right.$ sampai $\left.2^{10}\right)$. Menurut Anamu \& Rohi (2005), waktu yang diperlukan agar antibodi muncul dalam serum adalah 6 - 10 hari pasca infeksi, mencapai puncaknya pada 3 - 4 minggu kemudian menurun setelah kira-kira 3 - 4 bulan dan sudah tidak terdeteksi setelah $8-12$ bulan.

Selain untuk mengetahui status infeksi di lapangan, pembacaan titer antibodi melalui uji HI juga berperan dalam menentukan efektivitas program vaksinasi yang dilakukan. Hal ini berlaku untuk sampel darah hasil vaksinasi dan telah dilakukan oleh banyak peneliti (Darmawi et al., 2015 ; Kencana et al., 2015 ; Suryani, 2015 ; Santosa \& Sutrisna, 2017).

\section{Asosiasi Faktor Pemeliharaan dan Status Infeksi ND Pada Tingkat Peternakan}

Di antara beberapa variabel terkait faktor pemeliharaan yang diamati dalam penelitian ini, terlihat ada 2 faktor yang tidak dapat diukur asosiasinya, 2 faktor yang berasosiasi negaif, dan 7 faktor resiko yang berpengaruh kuat dalam penentuan status infeksi ND pada peternakan ayam buras (Tabel 3). Ketujuh variabel tersebut berdasarkan kekuatan asosiasinya berturut-turut : penggunaan kandang, perlakuan ayam sakit, perlakuan ayam mati, perlakuan ayam baru, penggunaan pagar kandang, perlakuan kotoran, dan sumber air minum,

Tabel 3. Asosiasi Faktor Pemeliharaan dan Status Infeksi ND Pada Tingkat Peternakan Ayam Buras di Kecamatan Teluk Ambon

\begin{tabular}{lc}
\hline Variabel & Risk Relative \\
\hline Penggunaan kandang & 1,88 \\
Frekuensi membersihkan kandang & 0,57 \\
Frekuensi membersihkan tempat & 0 \\
pakan dan minum & \\
Perlakuan kotoran & 1,46 \\
Sumber air minum & 1,33 \\
Perlakuan ayam sakit & 1,64 \\
Perlakuan ayam baru & 1,54 \\
Perlakuan ayam mati & 1,64 \\
Kontak dengan burung liar & $\mathrm{NA}$ \\
Penggunaan pagar kandang & 1,5 \\
Keberadaan pohon & $\mathrm{NA}$ \\
\hline
\end{tabular}

$* \mathrm{NA}=$ not available (bilangan pembagi $=0$ )

Populasi ayam yang dipelihara tanpa kandang memiliki resiko 1,88 kali terinfeksi virus ND. Hasil ini menunjukkan pentingnya fungsi kandang dalam mencegah penyebaran penyakit. Walaupun temuan di lapangan terdapat $71,5 \%$ peternak yang memiliki kandang, nyatanya bangunan ini hanya difungsikan sebagai tempat perteduhan saat malam hari sehingga peternak cenderung tidak mengabaikan konstruksi dan kebersihannya. Tidak ada pembagian kandang berdasarkan golongan umur, demikian pula kandang khusus untuk karantina. Hal ini menyebabkan percampuran ayam dalam berbagai golongan umur dan status kesehatan dan meningkatkan resiko penularan.

Faktor frekuensi pembersihan kandang memiliki kekuatan asosiasi lemah $(\mathrm{RR}=0,57)$ dengan status infeksi ND pada tingkat peternakan. Tidak ditemukan pengaruh yang berarti antara peternakan yang memiliki jadwal pembersihan kandang beberapa minggu sekali dan yang memiliki frekuensi beberapa kali dalam seminggu. Hasil ini tidak berbeda jauh dengan temuan Prasetyo (2012) pada peternakan unggas sektor IV di Kecamatan Cipunagara. Kondisi tersebut diduga akibat teknik pembersihan dengan peralatan sederhana dan tanpa penyemprotan desinfektan.

Kandang beserta peralatannya yang jarang dibersihkan dapat bertindak sebagai media penularan virus. Fakta ini dilaporkan oleh Siahaan (2007) yang menemukan bahwa kandang, tempat pakan dan minum yang kotor berkontribusi terhadap penyebaran ND dengan kekuatan asosiasi berturut-turut 12 kali, 5 kali, dan 4,85 kali lebih tinggi. Hal tersebut tidak berlaku di peternakan ayam buras di Kecamatan Teluk Ambon.

Kotoran kandang menjadi media efektif penularan berbagai agen penyakit (Soejoedono et al., 2005). Peternakan yang tidak menangani kotoran kandang dengan baik (misalnya dibakar atau ditanam) memiliki resiko 1,46 kali terinfeksi ND. Lebih lanjut, peternakan yang tidak memisahkan ayam sakit, ayam mati, maupun ayam dari luar peternakan memiliki peluang terinfeksi berturut-turut 1,64 kali, 1,64 kali dan 1,46 kali. Data ini menunjukkan pentingnya mempraktekan aspek biosekuriti. Pemisahan ayam baru dilakukan selama 2 minggu dan apabila menunjukkan gejala sakit harus diisolasi sejauh dan selama mungkin dari kandang utama (Zainuddin \& Wibawan, 2007 ; Hanson, 2008), sementara bangkai ayam mati wajib dibakar atau ditanam dengan kedalaman 1,3 meter kemudian ditutup tanah dan ditaburi kapur (Ryder, 2005 ; Damron, 2006).

Peternakan yang menggunakan air dari kali atau sungai sebagai sumber air minum memiliki peluang terpapar virus ND 1,33 kali lebih tinggi dibandingkan yang menggunakan air PAM atau sumur. Survei di lapangan menemukan ada $14,29 \%$ pemilik peternakan yang sengaja membuang bangkai ayam mati ke sungai atau kali terdekatdan kembali menggunakan air tersebut untuk air minum ayam dan membersihkan kandangnya. Sejalan dengan pendapat Soejoedono \& Handharyani (2005) bahwa perilaku tersebut semakin mempercepat penularan penyakit.

Penggunaan pagar dapat menekan resiko penularan penyaki terutama dari hewan carrier seperti rodensia dan insekta yang masuk ke dalam kandang 
untuk mengicar pakan sisa atau yang disimpan di gudang kandang. Tabel 3 memperlihatkan, peternakan ayam buras yang tidak memiliki pagar memiliki peluang terinfeksi ND 1,5 kali lebih tinggi. Mayoritas peternak $(76,19 \%)$ di lokasi penelitian tidak memiliki pagar karena beranggapan kandang sudah cukup melindungi ternak peliharaannya.

Keberadaan pohon besar di sekitar kandang patut diwaspadai karena seringkali menjadi tempat persinggahan burung-burung liar. Burung liar merupakan reservoir yang menularkan berbagai penyakit selain ND (Alexander \& Capua, 2008). Pada penelitian ini, kedua faktor tersebut tidak dapat dihitung kekuatan asosiasinya, walaupun selama pengamatan di lapangan frekuensi kontak antara ayam buras dan burung liar di sekitar lokasi peternakan cukup sering teramati. Penerapan prinsip biosekuriti yang meliputi kontrol lalu lintas hewan, pembersihan kandang dan peralatan, desain kontruksi kandang untuk meminimalkan kontak dengan hewan luar, serta penanganan ayam sakit dan mati secara benar tidak hanya berfungsi mengurangi resiko penyebaran virus ND tapi juga agen patogen lainnya (Dam et al., 2012 ; Prasetyo, 2012 ; Nugraha, 2015).

\section{SIMPULAN}

Peternakan ayam buras di Kecamatan Teluk Ambon yang positif terinfeksi ND sebanyak 66,67 \%. Faktor pemeliharaan yang beresiko terhadap penyebaran ND jika diurutkan berdasarkan besarnya kekuatan asosiasinya yaitu berturut-turut penggunaan kandang $(1,88)$, perlakuan ayam sakit $(1,64)$,perlakuan ayam mati (1,64),perlakuan ayam baru (1,54), penggunaan pagar $(1,5)$, perlakuan kotoran $(1,46)$, dan sumber air $(1,33)$.

\section{UCAPAN TERIMA KASIH}

Penulis mengucapkan terima kasih kepada alumni Jurusan Peternakan yaitu Helena Rahaningmas yang banyak berkontribusi pada penelitian ini. Ucapan yang sama ditujukan kepada Stasiun Karantina Kelas I Ambon untuk dukungan fasilitas serta teknisi dalam melakukan pengujian HA-HI.

\section{DAFTAR PUSTAKA}

Alexander, D. J. 2001. Newcastle Disease: The Gordon Memorial Lecture. British Poultry Science. 42(1): 5-22. DOI: 10.1080/713655022.

Alexander, D. J., \& I. Capua. 2008. Avian Influenza in Poultry. World's Poultry Science Journal. 64(04): 513-532. DOI: 10.1017/S0043933908000184

Anamu, S., \& O. K. Rohi. 2005. Studi Serologi dengan Uji Hambat Hemaglutinasi Terhadap Angsa yang dapat Bertindak sebagai Pembawa
Newcastle Disease di D. I. Yogyakarta. J. Sain Veteriner. 23(1): 8-12. DOI: https://doi.org/ $10.22146 / j s v .362$.

Bernadeta, I., I. Yuanita, \& L. Silitonga. 2015. Deteksi Antibodi Terhadap Avian Influenza pada Ayam Buras di Peternakan Rakyat Kota Palangka Raya. Jurnal Ilmu Hewan Tropika. 4 (1): 22-26.

[BPS] Badan Pusat Statistik. 2017. Kecamatan Teluk Ambon Dalam Angka. Ambon: Badan Pusat Statistik Kota Ambon.

[CFSPH] Center for Food Security and Public Health. 2008. Newcastle Disease. http://www.cfsph. iastate.edu. [08/04/2020].

Dam, A., P. Innes, \& P. Bowers. 2012. Biosecurity Recommendation for Small Flock Poultry Owners [Factsheet]. Norhtern Ontario (CA): Ministry of Agriculture, Food and Rural Affairs.

Damron, W. S. 2006. Introduction to Animal Science. Global, Biological, Social and Industry Perspectives. Third Edition. New Jersey: Pearson Education Inc (Prentice Hall).

Darmawi, Fakhrurrazi, Wiliana, M. Dewi, M. Abrar, F. Jamin, \& Z. H. Manaf. 2015. Deteksi Antibodi Serum Ayam Kampung (Gallus domesticus) terhadap Virus ND di Kota Banda Aceh. Jurnal Medika Veterinaria. 9(1): 5-8.

Hanson, J. G. 2008. Biosecurity for the Poultry Industry. http://www.wvu.edu/. [16/03/2020].

Kencana, G. A. Y., N. Suartha, M. P. Simbolon, A. N. Handayani, S. Ong, Syamsidan, \& A. Kusumawati. 2015. Respons Antibodi Terhadap Penyakit Tetelo pada Ayam yang Divaksin Tetelo dan Flu Burung. Jurnal Veteriner. 16(2): 283-290.

Martin, S.W., A. H. Week, \& P. Willenberg. 1987. Veterinary Epidemiology Principles and Methods. Ames: Iowa State University Press.

Nugraha, K. A. 2015. Studi Prevalensi Newcastle Disease Pada Unggas Peliharaan Masyarakat di Kecamatan Lore Utara Kabupaten Poso. [Skripsi]. Bogor: Institut Pertanian Bogor.

[OIE] Office International Epizootic. 2009. Newcastle Disease: Terrestrial Manual. http://www.oie.int. [31/3/2020].

Pertulla, L. 2009. Epidemiology and Charaterization of Newcastle Disease in Smallholder Poultry in Mozambique. [Thesis]. Uppsala: Sveriges lantbruksuniversitet.

Prasetyo, D. A. 2012. Faktor risiko terhadap infeksi virus ND (Newcastle Disease) pada peternakan unggas sektor IV di Kecamatan Cipunagara 
Kabupaten Subang. [Skripsi]. Bogor: Institut Pertanian Bogor.

Purnamawati, A., \& E. Surdanika. 2008. Kajian Hasil Vaksinasi Avian Influenza pada Ayam Buras Rakyat di Kabupaten Tasikmalaya. Proceeding of AZWMC, p. 281-283. Bogor, 19-21 Agustus 2008.

Rajab, \& B. J. Papilaya. 2012. Sifat Kuantitatif Ayam Kampung Lokal pada Pemeliharaan Tradisional. Agrinimal Jurnal Ilmu Ternak dan Tanaman. 2(2): 61-64.

Ryder, C. L. 2005. Agriculture Department Closes Live Bird Marke in philadelphia: No threat to human health of food safety. http://www.agriculture.state.pa.us/.[16/02/2020]

Santhia, K. 2003. Strategi Diagnosa dan Penanggulangan Newcastle Disease. Prosiding Seminar Regional Perunggasan. Universitas Udayana, Denpasar, 26 Oktober 2003.

Santosa, P. E., \& R. Sutrisna. 2017. Titer Antibodi Avian Influenza dan Newcastle Disease dalam Serum Darah Itik Grower yang Diberi Ransum Berbeda Kadar Protein Kasar dan Divaksin dengan Vaksimune NDL AI. Jurnal Penelitian Pertanian Terapan. 17(1): 11-16.

Siahaan, S. J. 2007. Pengaruh Tingkat Biosekuriti Terhadap Pemaparan Avian Influenza Pada Unggas Air. [Tesis]. Bogor: Program Pasca Sarjana, Institut Pertanian Bogor.

Soeharsono. 2005. Zoonosis Penyakit Menular dari Hewan ke Manusia. Yogyakarta: Penerbit Kanisius.
Soejoedono, R. D, \& E. Handharyani. 2005. Flu Burung. Jakarta: Penebar Swadaya.

Soejoedono, R. D., I. W. T. Wibawan, \& Z. Hayati. 2005. Pemanfaatan Telur Ayam Sebagai Pabrik Biologis: Produksi "Yolk Immunoglobulin" (IgY) Anti Plaque dan Diare dengan Titik Berat pada Anti Streptococcus mutans, Escherichia coli dan Salmonella enterotidis. Laporan Riset Unggulan Terpadu. Kementerian Negara Riset dan Teknologi, Jakarta.

Suryani, L. 2015. Deteksi Titer Antibodi dan Identifikasi Faktor Penyebab Kegagalan Vaksinasi terhadap Newcastle Disease pada Ayam Petelur di Desa Bulo Kabupaten Sidenreng Rappang. [Skripsi]. Makasar: Program Studi Kedokteran Hewan, Fakultas Kedokteran, Universitas Hasanuddin.

Syukron, M. U., I. N. Suartha, \& N. S. Dharmawan. 2013. Serodeteksi Penyakit Tetelo pada Ayam di Timor Leste. Indonesia Medicus Veterinus. 2(3): 360-368.

Tabbu, C. R. 2000. Penyakit Ayam dan Penanggulangannya: Penyakit Bakterial, Mikal, dan Viral. Volume 1. Yogyakarta: Penerbit Kanisius.

Wibowo, M. H., \& S. Amanu. 2010. Perbandingan Beberapa Program Vaksinasi Penyakit Newcastle pada Ayam Buras. Jurnal Sain Veteriner. 28(1): 27-35. DOI: https://doi.org/ $10.22146 / j s v .446$.

Zainuddin, D., \& W. T. Wibawan. 2007. Biosekuriti dan Manajemen Penanganan Penyakit Ayam Lokal. http://www.peternakan.litbang.deptan. go.id/. [04/04/2020]. 